City University of New York (CUNY) CUNY Academic Works

2011

\title{
Was the Black Death in India and China?
}

George D. Sussman

CUNY La Guardia Community College

\section{How does access to this work benefit you? Let us know!}

More information about this work at: https://academicworks.cuny.edu/lg_pubs/52

Discover additional works at: https://academicworks.cuny.edu

This work is made publicly available by the City University of New York (CUNY).

Contact: AcademicWorks@cuny.edu 


\title{
Was the Black Death in India and China?
}

\author{
GEORGE D. SUSSMAN
}

\begin{abstract}
Summary: Firsthand accounts of the Black Death in Europe and the Middle East and many subsequent historians have assumed that the pandemic originated in Asia and ravaged China and India before reaching the West. One reason for this conviction among modern historians is that the plague in the nineteenth century originated and did its worst damage in these countries. But a close examination of the sources on the Delhi Sultanate and the Yuan Dynasty provides no evidence of any serious epidemic in fourteenth-century India and no specific evidence of plague among the many troubles that afflicted fourteenth-century China.
\end{abstract}

KEYwords: plague, Black Death, India, China

Gabriele de' Mussis, the fourteenth-century lawyer from Piacenza whose "Historia de Morbo" is one of the most informative and moving contemporary accounts of the Black Death, ${ }^{1}$ believed that the pandemic was

Research for this article was made possible by a Fellowship Leave from LaGuardia Community College, The City University of New York (CUNY), for which I am grateful. I would also like to thank the libraries of CUNY, the New York Public Library, which gave me access to the Wertheim Study during the period of my leave, and the New York Academy of Medicine and its Rare Book Room. Finally, I am indebted to Jo N. Hays, Kevin Reilly, Jeremy Sussman, Nancy Hathaway, and three anonymous readers for the Bulletin of the History of Medicine for their helpful criticism of earlier drafts of this article.

1. Throughout this paper I use the term "Black Death" to refer to the devastating plague epidemic that swept through Europe and the Middle East between 1347 and 1352. After this initial invasion, the plague returned to Europe and the Middle East repeatedly for three to five hundred years (until 1711 in northwestern Europe, until 1743 in southern Europe, until 1770 in eastern Europe, and until 1842 in the Middle East). Plague historians refer to this long wave of epidemic outbreaks—from 1347 to 1842 — as the second plague pandemic, to distinguish it from an earlier and a later wave of epidemic plague outbreaks. The first plague pandemic traveled from the Egyptian seaport of Pelusium in $541 \mathrm{CE}$ to Constantinople, where it was known as the Plague of Justinian, in 542 and spread sporadically throughout the Middle East and Mediterranean Europe until 767. The third pandemic first received worldwide notice in Hong Kong and Canton in 1894, spread from there by steamship to seaports in India, Africa, Australia, and South and North America, and has continued at least until an outbreak in 1994 in Surat, India. 
universal, by which he meant that it affected the Eurasian landmass and the Mediterranean Basin-all of the world known to him. At one moment in his narrative he embraced the people of the known world not only in the experience of the plague pandemic, but also in his Christian perception of that experience:

The scale of the mortality and the form which it took persuaded those who lived, weeping and lamenting, through the bitter events of 1346 to 1348 - the Chinese, Indians, Persians, Medes, Kurds, Armenians, Cilicians, Georgians, Mesopotamians, Nubians, Ethiopians, Turks, Egyptians, Arabs, Saracens and Greeks (for almost all the East has been affected) — that the last judgment had come. ${ }^{2}$

At another moment he mixed the exoticism of travelers' tales of the East with the horror of the plague experience:

In the East, in Cathay, which is the greatest country in the world, horrible and terrifying signs appeared. Serpents and toads fell in a thick rain, entered dwellings and devoured numberless people, injecting them with poison and gnawing them with their teeth. In the South, in the Indies, earthquakes cast down whole towns and cities were consumed by fire from heaven. The hot fumes of the fire burnt up infinite numbers of people, and in some places it rained blood, and stones fell from the sky. ${ }^{3}$

In both passages de' Mussis expressed his conviction that the other, still barely known civilizations of Asia shared in Europe's nightmare.

Somewhat closer to China and India another eyewitness, Ibn al-Wardi of Aleppo, gathered information on the origins of the plague from Muslim merchants returning to Syria from the Crimea. Al-Wardi, who was himself to die of the plague in March 1349, shortly after he wrote these words, declared that the pandemic had begun in "the land of darkness" (northern Asia) and that it had been active for fifteen years: "China was not preserved from it, nor could the strongest fortress hinder it. The plague afflicted the Indians in India. It weighed upon the Sind. It seized with its

2. Gabriele de' Mussis, "The Arrival of the Plague [Historia de Morbo]" in The Black Death, ed. Rosemary Horrox (Manchester, UK: Manchester University Press, 1994), 14-26, quotation on 18. For an interesting discussion of the perception of the Black Death as universal, see Ann G. Carmichael, "Universal and Particular: The Language of Plague, 1348-1500," in Pestilential Complexities: Understanding Medieval Plague, ed. Vivian Nutton, Supplement 27 to Med. Hist. (London: Wellcome Trust for the History of Medicine at UCL, 2008), 17-52.

3. Mussis, Black Death (n. 2), 25. 
hand and ensnared even the lands of the Uzbeks. How many backs did it break in what is Transoxiana! The plague increased and spread further."

The modern historiography of the Black Death began with the pioneering German medical historian J. F. C. Hecker's extended essay of 1832, which branded the fourteenth-century pandemic with the name it bore in Germany and northern Europe, der Schwarze Tod. Hecker shared the views of medieval chroniclers on its geographic impact: "an universal pestilence, which extended from China to Iceland and Greenland. ${ }^{5} \mathrm{He}$ traced the "oriental plague" back to a bubbling cauldron of misfortunesdrought, famine, flooding, collapsing mountains, locusts, earthquakes, a falling meteor, and epidemics — that afflicted China beginning in 1333, while noting other atmospheric events in the same period in Europe. Still closer to a miasmatic theory of disease than to the germ theory, Hecker viewed the movement of the plague from east to west as "a progressive infection of the Zones" above and below the earth's surface rather than as a chain of contagion. ${ }^{6}$

William H. McNeill, in his classic Plagues and Peoples (1976), informed by the germ theory of disease causation and transmission, nevertheless perpetuated the traditional view of the Eurasian scope of the Black Death: "Scholarly discussion of the Black Death in Europe, its course and consequences, is more than a century old; nothing remotely comparable exists for other regions of the earth. Yet it is impossible to believe that the plague did not affect China, India, and the Middle East."7 Michael W. Dols began to fill the void of scholarship referred to by McNeill with the publication of his book, The Black Death in the Middle East, the year after Plagues and Peoples appeared. ${ }^{8}$ But nothing comparable has appeared to fill the voids on the Black Death in India and China, voids that McNeill imaginatively attempted to fill through his understanding of the epidemiology of plague and his broad general knowledge of world history.

4. Michael Dols, "Ibn al-Wardi's Risalah al-Naba' 'An al-Waba': A Translation of a Major Source for the History of the Black Death in the Middle East," in Near Eastern Numismatics, Iconography, Epigraphy and History: Studies in Honor of George C. Miles, ed. Dickran K. Kouymjian (Beirut: American University of Beirut, 1974), 443-55, quotations on 444, 448.

5. J. F. C. Hecker, M.D., "The Black Death," in The Epidemics of the Middle Ages, 3rd ed., trans. B. G. Babington, M.D. (London: Trübner \& Co., 1859), xx-62, quotation on xxiii. Hecker's essay was initially published and immediately translated into English in 1832, when another "universal pestilence," cholera, had spread from Asia to Europe.

6. Ibid., 11-17, quotation on 17.

7. William H. McNeill, Plagues and Peoples (1976; repr., New York: Anchor, 1998), 196.

8. Michael W. Dols, The Black Death in the Middle East (Princeton, N.J.: Princeton University Press, 1977). 
Today, over thirty years after McNeill's Plagues and Peoples, we still cannot state with any degree of assurance whether the Black Death, which marked such a caesura in European history, even visited China or the Indian subcontinent in the fourteenth century, much less what impact it might have had in either of these civilizations. Ironically, much of our modern understanding of the plague derives from research conducted in China and India in the late nineteenth and early twentieth centuries during the third pandemic, which first appeared in China and then spread to India, where it took the largest number of victims. ${ }^{9}$ The prominence of China and India in the third pandemic has certainly contributed to the conviction that these regions must also have played a prominent role in the beginning of the second pandemic, the Black Death.

In the present article I first review the historical geography of the plague. Then I argue that the Black Death almost certainly did not appear in India in the fourteenth century, despite the intimate ties that linked the Delhi Sultanate of northern India with central Asia and the Middle East, areas ravaged by the epidemic. Finally, I argue that China, although wracked by widespread, lethal epidemics in the mid-fourteenth century, also may not have experienced the Black Death.

\section{The Original Foci of Plague}

The so-called first plague pandemic struck the Byzantine Emperor Justinian's capital of Constantinople in $542 \mathrm{CE}$, when the disease was clinically described by the historian Procopius. Following that outbreak the plague meandered about the shores of the Mediterranean and inland on three continents for the next two hundred years. ${ }^{10}$ Procopius traced the plague of Constantinople back to the Egyptian port of Pelusium, located where the easternmost branch of the Nile delta empties into the Mediterranean Sea. The initial appearance of the first pandemic in Pelusium, rather than the busier port of Alexandria farther to the west, suggests its importation

9. Myron Echenberg, "Pestis Redux: The Initial Years of the Third Bubonic Plague Pandemic, 1894-1901," J. World Hist. 13, no. 2 (2002): 429-49; Myron Echenberg, Plague Ports: The Global Urban Impact of Bubonic Plague, 1894-1901 (New York: New York University Press, 2007).

10. For an excellent recent collection on the first pandemic see Lester K. Little, ed., Plague and the End of Antiquity: The Pandemic of 541-750 (New York: Cambridge University Press, 2007). Procopius's account of the outbreak of 542-43 in Constantinople is found in Procopius, History of the Wars, II:xxii-xxiii, in Procopius, trans. H. B. Dewing (New York: Macmillan, 1914), 1:451-73. 
from the Red Sea or the caravan routes connecting to the Red Sea. ${ }^{11}$ This in turn suggests that the plague could have originated in either east Africa or south Asia, the two major destinations of commercial traffic in the Red Sea. ${ }^{12}$ McNeill observed, "the disease must have penetrated the Mediterranean from an original focus either in northeastern India or in central Africa."13

McNeill's specificity here-northeastern India and central Africa-leads back to a larger argument in Plagues and Peoples. McNeill argues, following earlier plague researchers, that the bubonic plague is first of all a disease of burrowing rodents that has occasionally spread to humans either directly from those wild rodents and their fleas or indirectly from domestic rats that acquired the disease from the wild rodents. The plague bacillus, Yersinia pestis, is preserved in the burrows and bodies of certain populations of wild rodents around the world, populations referred to as plague reservoirs or plague foci. Most of these foci were established in the third pandemic (beginning in 1894), when infected rats boarded steamships in Hong Kong, initially, and spread the bacillus to seaports in India, Australia, Africa, and South and North America. Three foci, according to McNeill, "are much older: one in the foothills of the Himalayas between India and China; one in central Africa in the region of the Great Lakes; and one scattered across the entire length of the Eurasian steppe from Manchuria to the Ukraine." ${ }^{14}$ A basic and original argument of McNeill is that the African and Indian foci of the plague date back to at least the beginning of the Common Era, while the steppe reservoir dates only from the fourteenth century.

The concept of plague foci or reservoirs assumes an understanding of the germ theory of disease and specific knowledge of the plague bacillus and the hosts and vectors involved in its transmission. The discovery of the bacillus occurred in Hong Kong in 1894, in the infancy of the germ theory, when Alexandre Yersin, a Swiss physician dispatched by the Pasteur Institute in Paris, and Kitasato Shibasaburo, a Japanese student of Robert

11. The Church lawyer and historian Evagrius Scholasticus, from Antioch, Syria, wrote fifty years after the initial invasion that the plague had come from Ethiopia, also abutting the Red Sea. Evagrius Scholasticus, The Ecclesiastical History of Evagrius Scholasticus, trans. Michael Whitby (Liverpool, UK: Liverpool University Press, 2000), “Introduction” and 229.

12. See the argument on this point in Michael McCormick, "Toward a Molecular History of the Justinianic Pandemic," in Little, Plague and the End of Antiquity (n. 10), 290-312, esp. 303-4.

13. McNeill, Plagues and Peoples (n. 7), 137.

14. Ibid., 139. 
Koch, competed to discover the micro-organism responsible for plague. Kitasato published first, but Yersin provided the more accurate and complete description of the bacillus, which was eventually named for him. ${ }^{15}$ Although Yersin also found plague bacilli in infected rats, it was another Pasteurian, Paul-Louis Simond, working in India in 1898, who proposed the complete chain of transmission from rat to rat flea to human, a theory that was not fully demonstrated and accepted for another decade. ${ }^{16}$

In spite of the long-held assumption that the Black Death originated in Asia, before the third plague pandemic Western medical scientists were barely aware of the existence of plague beyond Europe, North Africa, and the Middle East. Dr. August Hirsch, professor of medicine at the University of Berlin, wrote in the second edition of his Handbook of Geographical and Historical Pathology (1881),

Until quite recently, everyone considered it settled that Persia was the eastern limit of the area of plague on Asiatic soil, beyond which, during the last five centuries at least, it had never penetrated. But the latest observations in India and China have completely upset that opinion. They have furnished us with extremely interesting facts as to great centres of plague in the interior regions of Eastern Asia; and this addition to our knowledge is all the more calculated to arrest the attention, for the reason that these centres belong not only to the past, but remain unimpaired down to the present day. ${ }^{17}$

The discoveries that Hirsch refers to were those of plague outbreaks and endemic centers of plague in India and China in the nineteenth century. These included an outbreak in western India, including the states of Gujarat and Sind, in 1815-21, and another in the present-day state of Rajasthan in northwestern India in 1835-38. The endemic sites he identified were a "centre of plague on the southern slopes of the Himalaya and in the provinces of Kumaon and Gharwal, the existence of which can be traced back with certainty to the year 1823," and "a pestilential centre in China, of an extent at present undetermined, the existence of which was brought to notice first in some recent publications, although it is unquestionably of older date." ${ }^{18}$ Kumaon and Garhwal (Hirsch's Gharwal) are located on the Himalayan frontier of India to the northwest of Nepal in the present-

15. Echenberg, Plague Ports (n. 9), 33-35.

16. Ibid., 69-70.

17. Dr. August Hirsch, Handbook of Geographical and Historical Pathology, vol. 1, Acute Infective Disease, trans. Charles Creighton, M.D. (2nd German ed. 1881; repr., London: New Sydenham Society, 1883), 508.

18. Ibid., 1:509-10, emphasis original. 
day states of Uttarakhand and Himachal Pradesh. The "pestilential center" in China was in the mountain valleys of the southwestern province of Yunnan, adjacent to Burma, from which the plague might have been imported. The plague, Hirsch reported, had been confined to the western part of Yunnan "previous to the outbreak of the revolution"-a reference to a Muslim rebellion that began in 1856-and had subsequently spread throughout the entire province, reaching epidemic proportions in 1871-73. ${ }^{19}$ Finally, Hirsch observed that the recent experience of plague in India and Arabia had overturned another previously "uncontested doctrine," namely that the plague did not spread into tropical climates. That belief had been based on the fact that plague had never in modern times spread south from Egypt into Nubia or Abyssinia. ${ }^{20}$

Thus, in 1881, on the eve of the germ revolution, the documented knowledge of the existence of plague in China and India was quite recent and included only nineteenth-century outbreaks. The idea of certain "endemic centers" of plague prefigured the later, more precise concept of plague foci. Sub-Saharan Africa was still out of the picture.

With the discovery of the plague bacillus and of the means of plague transmission in the early years of the third pandemic, the concept of endemic centers of plague took on a different meaning. While "endemic centers" for Hirsch referred to places where the plague was perennially present, judging from the frequent occurrence of plague symptoms in the human population, by the early twentieth century a plague focus designated a place where plague bacilli had been found infecting a population of wild, burrowing rodents. Thus plague historian Georg Sticker, writing in 1910, used the term Pestherde - a population of plague-infected animals - for what epidemiologists today would call a plague reservoir or plague focus. ${ }^{21}$ In 1923 the Western-trained Chinese plague researcher Dr. Wu Lien-teh counted twelve different plague foci that antedated the beginning of the third pandemic in 1894. Two of Wu's plague foci were in Africa: one in Benghazi in modern Libya and the other in central Africa near Lake Victoria. The other ten plague foci were in Asia: They were Assyr in northern Yemen, the region of Kurdistan in western Asia, Kumaon and Gurwhal (Garhwal) in northern India, part of Yunnan

19. Ibid., 1:510-11. I will discuss the plague in nineteenth-century Yunnan, the origin of the third plague pandemic, later in this article.

20. Ibid., 1:514.

21. Georg Sticker, Abhandlungen aus der Seuchengeschichte und Sechenlehre. I. Band. Die Pest. Erster Teil: Die Geschichte der Pest (Giessen, Germany: Verlag von Alfred Töpelmann, 1908-10), 294, 326, for example. 
Province in China, Transbaikalia and Outer Mongolia, Inner Mongolia, Tibet, Turkestan, Persia, Astrakhan, and adjoining territories..$^{22}$ Reviewing these plague foci one by one, Wu identified many of them by disease outbreaks in the nineteenth century. In some he confirmed the presence of plague bacilli in specific rodent species. Thus, for the central African focus he noted that Koch and Zupitza in 1897 had found plague among the rats infesting banana groves, undoubtedly a reference to a microscopic inspection. "This plague focus is apparently of very old age," Wu commented, although he allowed that "for some of the outbreaks east of the Victoria Nyanza [Lake Victoria], importation from India [in the third pandemic] is probable or possible." Believing that "the original home" of plague is "somewhere in Asia, which is the first habitation of rodents," Wu found it difficult to explain the origin of the central African focus. ${ }^{23}$

In Kumaon and Garhwal, a sparsely populated region of India at an elevation of three thousand to six thousand feet, "the population is well acquainted with the disease, and flies in time of danger from the affected villages into the forests." ${ }^{24}$ A German Plague Commission had traced the endemicity there to local rodents. In Transbaikalia and Outer Mongolia hunters and local residents had known that the plague infected marmotlike tarabagans for decades before scientists conducted bacteriological tests on humans in 1905 (and Wu's own laboratory found bacilli in the tarabagans during the pneumonic plague pandemic of 1910-11 in Manchuria). Indeed, Wu regarded the whole of the central Asian plateau, from Transbaikalia in the north to Kumaon and Garhwal on the south slope of the Himalayas, from Inner Mongolia in the east to Kurdistan in the west, as "one huge endemic area," where plague was kept alive by various species of hibernating, burrowing rodents. He believed this region was the original home of the epidemic. ${ }^{25}$

22. Wu Lien-teh, "The Original Home of Plague," in Far Eastern Association of Tropical Medicine, Transactions of the Fifth Biennial Congress Held at Singapore, 1923, ed. A. L. Hoops and J. W. Scharff (London: John Bale, Sons \& Danielsson, 1924), 286-304. For information on Wu Lien-teh and his leading role in the Manchurian pneumonic plague pandemic of 1910-11, see Wu Lien-teh, Plague Fighter: The Autobiography of a Modern Chinese Physician (Cambridge, UK: W. Heffer, 1959); Carsten Flohr, "The Plague Fighter: Wu Lien-teh and the Beginning of the Chinese Public Health System," Ann. Sci. 53 (1996): 361-80; Carl F. Nathan, Plague Prevention and Politics in Manchuria, 1910-1931 (Cambridge, Mass.: Harvard University Press, Harvard East Asian Monographs, 1967); Mark Gamsa, "The Epidemic of Pneumonic Plague in Manchuria, 1910-1911," Past Pres. 190 (February 2006): 147-83.

23. Wu, "Original Home of Plague" (n. 22), 289. On Koch and the central African focus of plague, see Myron Echenberg, “'Scientific Gold': Robert Koch and Africa, 1883-1906," in Agency and Action in Colonial Africa: Essays for John E. Flint, ed. Chris Youé and Tim Stapleton (New York: Palgrave, 2001), 34-49, esp. 42-43.

24. Wu, "Original Home of Plague" (n. 22), 292.

25. Ibid., 293, 294, 300. 
There are important differences between William McNeill and Wu Lien-teh on the foci of plague that existed before 1894 and that might have been at the origin of the Black Death. Both men identify a central African focus that they believe was ancient, although neither can point to any evidence of its existence before the nineteenth century. Wu's other African focus, in modern Libya, was almost certainly established in the aftermath of the Black Death. ${ }^{26}$ In Asia Wu speaks of one gigantic focus extending across the central Asian plateau that he believes was the original focus of the plague. McNeill prefers to distinguish between two smaller foci separated by the Tibetan Plateau, one ancient one in the Himalayan foothills between India and China and another along the Eurasian steppe, which was established only in the fourteenth century. His Indian focus, as we will see, certainly refers to the northeast corner of India adjacent to Burma and Yunnan in southwest China. Whether he means to include in the Indian focus Kumaon and Garhwal, also in the Himalayan foothills but hundreds of miles to the west of Burma and Yunnan, is not clear.

The ultimate origin of the second plague pandemic, according to McNeill, was the same as that of the third pandemic: the Burma-Yunnan focus. In 1252-53 Mongol horsemen penetrated southward from the steppes into Yunnan and Burma. McNeill believes that some of these invaders carried infected rats and fleas back to their Mongolian homeland in their saddlebags "stuffed with grain or some other form of booty." ${ }^{27}$ In the steppes the fleas infected wild rodent species and created the third great plague focus. Infected rodents and fleas, on their own or borne by Mongolian horsemen or Silk Road caravans, carried the plague pathogen over nearly a century westward to the Crimea, where it ignited the Black Death in 1346, and eastward to China. ${ }^{28}$ McNeill's thesis fits with al-Wardi's report that the epidemic came from "the land of darkness." It also fits with an isolated report from 1885 by the Russian archaeologist Daniel Abramovich Chwolson. Chwolson excavated two medieval cemeteries of Nestorian Christian traders a few miles west of Lake Issyk-Kul on the northern border of present-day Kirghizstan. On 330 headstones found in the cemeteries he counted the names of 650 people who had died between the years 1186 and 1349. At least 106 of the dead died in only two years, 1338-39, and 3 of the headstones from those years bearing

26. Georg Sticker traces the Benghazi plague focus via caravan route back to Nubia and ultimately to the central African focus. Sticker, Abhandlungen (n. 21), I:326

27. McNeill, Plagues and Peoples (n. 7), 172.

28. Ibid., 171-73. 
10 names attributed the deaths to "pestilence" (in Syriac). ${ }^{29}$ This is the only evidence we have of a possible plague outbreak in the steppes before the reports from the Crimea in 1346, to which the European and Middle Eastern epidemics have been traced.

In 1977, the year after McNeill published Plagues and Peoples, John Norris advanced another theory for the geographic origin of the Black Death in an article in the Bulletin of the History of Medicine. Norris argued that the Black Death did not originate in central Asia at all, but in the plague focus in Kurdistan. From there, he argued, the plague pathogen moved northward over centuries via wild rodent colonies to southeastern European Russia (between the lower reaches of the Don and Volga Rivers), from whence it spread to Europe and the Middle East as the Black Death. Neither China nor India, Norris thought, was infected at the time of the Black Death. ${ }^{30}$

Norris built his case from several different arguments. First, he noted the absence of any firsthand description of plague or its symptoms in Mongol sources or in the writings of merchants and travelers on the Silk Road anywhere to the east of the Caucasus and the northern shore of the Black Sea in the years leading up to the Crimean outbreak of $1346 .{ }^{31}$ Norris dismissed Chwolson's excavation of the Nestorian cemetery near Issyk Kul as evidence of "a sporadic, small-scale outbreak ... characteristic of direct transmission from wild rodents to small, dispersed, human populations," with no wide-scale impact. ${ }^{32}$ Further, he made the important point that the Silk Road in the fourteenth century was no longer the open highway it had been a century before. The three western Mongol khanates-the Ilkhanate in Persia, the Kipchak Khanate or Golden Horde in southern Russia, and the Chaghatid Khanate in central Asia-had all converted to Islam around the beginning of the fourteenth century and no longer accepted the authority of the Grand Khan or qaghan, who had become more the emperor of China than the leader of the Mongolian world

29. John Norris, "East or West? The Geographic Origin of the Black Death," Bull. Hist. Med. 51, no. 1 (Spring 1977): 1-24, 10; R. Pollitzer, M.D., Plague (Geneva: World Health Organization, 1954), 1-24, esp. 14. Robert Pollitzer was initiated into plague research as a young assistant to Wu Lien-teh in the Manchurian pneumonic plague epidemic of 1910-11. See Wendy Orent, Plague: The Mysterious Past and Terrifying Future of the World's Most Dangerous Disease (New York: Free Press, 2004), 201-2.

30. Norris, "East or West?" (n. 29), 1, 3-7.

31. Ibid., 7.

32. Ibid., 13. In addition, as Ole Benedictow observes, the term pestilence on the tombs near Lake Issyk Kul could refer to any epidemic disease. Ole J. Benedictow, The Black Death, 1346-1353: The Complete History (Rochester, N.Y.: Boydell, 2004), 44. 
empire since Qubilai had moved his capital from Karakorum (in Mongolia) to Ta-tu (modern Beijing) in 1260. Western and Persian traders found trade along the Silk Road difficult after 1325 and impossible by $1340 .{ }^{33}$ Moreover, in the fifteen years before the plague outbreak in the Crimea there was hardly any military movement between the Golden Horde and the khanates to the east, although there was perpetual fighting between the Golden Horde and the Ilkhanate to the south. ${ }^{34}$ In short, there was not much human traffic to give an assist to plague bacilli traveling from east to west across the broad and thinly populated Eurasian steppes.

A final aspect of Norris's argument derived from an influential article by Dr. R. Devignat published in 1951 that identified three varieties of the plague bacillus based on biochemical reactions they produced. Dr. Devignat was the director of a medical laboratory in the Belgian Congo near Lake Albert. He collected reports from all over the world on the capacity of local samples of Yersinia pestis to ferment glycerine and to reduce nitrates to nitrites. From these reports he distinguished three varietiesoften called "biovars" - of the plague bacillus: those that could produce both reactions, those that could produce only one, and those that could produce only the other. Observing the geographical distribution of these three biovars around the world in his own day and drawing on his own, sometimes speculative knowledge of the spread of the plague historically, Devignat distinguished between primary foci, where specific varieties first appeared, and secondary foci, to which they had spread. Thus, for example, the biovar that did not ferment glycerine but did reduce nitrates had a primary focus in Burma, India, and south China, from which it had spread in the third pandemic to secondary foci in North and South America. Based on their primary foci Devignat attributed each of the three historic plague pandemics to one of the three biovars of the plague bacillus, which he therefore named Antigua, Mediaevalis, and Orientalis. ${ }^{35}$ The

33. Peter Jackson suggests a different chronology of the Silk Road trade. He claims that the years from about 1320 to about 1345 were the heyday of direct European overland trade with India and the Far East, "the era in which Western merchants, relatively few in number, travelled beyond Tana [near the mouth of the Don River] and Tabriz [in northwestern Iran], to participate personally in commercial ventures in the Indian subcontinent, in Central Asia, or in China." Peter Jackson, The Mongols and the West, 1221-1410 (New York: Pearson Longman, 2005), 301.

34. Norris, "East or West?" (n. 29), 13-15.

35. Dr. R. Devignat, "Variétés de l'espèce Pasteurella pestis: Nouvelle hypothèse," Bull. World Health Organization 4 (1951): 247-63. Recent genetic research analyzing the DNA of $Y$. pestis found in the remains of European plague victims in the first and second pandemics 
three biovars, the places where each was found in the twentieth century, and their distinctive biochemical properties are presented on Table 1.

Table 1. The Three Biovars of Plague

\begin{tabular}{|c|c|c|c|}
\hline \multirow[t]{2}{*}{ Name } & \multirow{2}{*}{$\begin{array}{l}\text { Geographical location in } \\
\text { twentieth century }\end{array}$} & \multicolumn{2}{|c|}{ Biochemical properties } \\
\hline & & $\begin{array}{l}\text { Ferments } \\
\text { glycerine }\end{array}$ & $\begin{array}{l}\text { Reduces } \\
\text { nitrates }\end{array}$ \\
\hline Antigua & Central Asia, central Africa & Yes & Yes \\
\hline Mediaevalis & $\begin{array}{l}\text { Southeast European Russia, } \\
\text { around Caspian Sea, Kurdistan }\end{array}$ & Yes & No \\
\hline Orientalis & $\begin{array}{l}\text { India, Burma, south China, } \\
\text { North and South America }\end{array}$ & No & Yes \\
\hline
\end{tabular}

Devignat could not say for sure what was the primary focus of the Antigua strain, although he speculated that it was in central Asia, from whence the Aryans had spread it to the Mediterranean and traders had carried it up the Nile River to the Lake District of central Africa in the early centuries of the Common Era. The Mediaevalis might have been an adaptation, over centuries, of the central Asian Antigua strain, as he believed the Orientalis strain, whose primary focus was in south China, Burma, and India, was as well. ${ }^{36}$

Historians of disease, beginning with Devignat himself, have often suggested that the different strains of plague may account for the greater

\footnotetext{
does not support Devignat. Two studies conducted by the team of Michel Drancourt in Marseille found only the Orientalis biovar among victims of the first two pandemics in southern France, while another by a team led by Stephanie Haensch of Mainz found Yersinia pestis of neither the Medievalis nor Orientalis biovar in remains of victims of the second pandemic in various northern European sites. Michel Drancourt, Véronique Roux, La Vu Dang, Lam Tran-Hung, Dominique Castex, Viviane Chenal-Francisque, Hiroyuki Ogata, Pierre-Edouard Fournier, Eric Crubézy, and Didier Raoult, "Genotyping, Orientalis-like Yersinia pestis, and Plague Pandemics,” Emerg. Infect. Dis. 10, no. 9 (September 2004): 1585-92; Michel Drancourt, Michel Signoli, La Vu Dang, Bruno Bizot, Véronique Roux, Stéfan Tzortzis, and Didier Raoult, "Yersinia pestis Orientalis in Remains of Ancient Plague Patients," Emerg. Infect. Dis. 13, no. 2 (February 2007): 332-33; Stephanie Haensch, Raffaella Bianucci, Michel Signoli, Minoarisoa Rajerison, Michael Schultz, et al., "Distinct Clones of Yersinia pestis Caused the Black Death," PLoS Pathog. 6, no. 10 (2010): 1-8, doi:10.1371/journal.ppat.1001134.

36. Devignat, "Variétés de l'espèce Pasteurella pestis" (n. 35), 254-55.
} 
virulence of the ancient and medieval epidemics in comparison with the third pandemic or for the greater tendency of the "earlier" strains to attack the lungs (become pneumonic) ${ }^{37}$ Others have suggested that these differences should be traced not to the different biovars, but to the different rodent hosts infected by each strain. John Norris is to my knowledge the only writer on historic plague epidemics to suggest an evolutionary explanation of the biochemical differences among Devignat's three biovars. "The development in the plague micro-organism of the capacity to ferment glycerine," he wrote, "is part of the adaptation to hibernating rodents." 38 Glycerine, he explained, builds up in the fat of hibernating rodents; through fermentation Yersinia pestis broke down this glycerine buildup for its own use. As the plague bacillus moved northward from warmer Kurdistan through the Caucasus and into the Russian steppe, where hibernation was a rodent adaptation to colder temperatures, natural selection favored the trait of fermenting glycerine in the rodents' parasite. For Norris, this is an argument for the northward spread of Yersinia pestis from its Kurdish focus to the jumping-off point of the Black Death in the Crimea in the mid-fourteenth century. ${ }^{39}$ In any event, the difference between the biovar of southwest China (Orientalis) and those of central Asia (Antigua) and southern Russia (Mediaevalis) would seem to undercut McNeill's suggested route for the Black Death from Yunnan to Mongolia to the Crimea.

Thus Norris contradicts McNeill's speculation about a Mongol-borne or -assisted plague traveling from Yunnan to Mongolia to the Crimea in three ways. First, he notes the absence of any documentary evidence of plague in the central and east Asian steppes in the fourteenth century. Second, he argues the implausibility of the germ traveling across the thinly populated steppes at a time when trade on the Silk Road and political and military relationships among the parts of the former Mongol Empire had diminished significantly. Third, he notes the biological difference between the strain of plague endemic today in Mongolia and those endemic today

37. Robert Sallares, "Ecology, Evolution, and Epidemiology of Plague," in Little, Plague and the End of Antiquity (n. 10), 231-89, esp. 281; John Theilmann and Frances Cate, "A Plague of Plagues: The Problem of Plague Diagnosis in Medieval England.” J. Interdiscip. Hist. 37, no. 3 (Winter 2007): 371-93, esp. 381-83; Susan Scott and Christopher J. Duncan, Biology of Plagues: Evidence from Historical Populations (New York: Cambridge University Press, 2001), 51-53; Orent, Plague (n. 29), 58-60.

38. Norris, "East or West?" (n. 29), 22.

39. Ibid., 22-24. 
either in south China, where McNeill suggests the Black Death originated, or in southeast European Russia, where its presence was first recorded.

\section{Was the Black Death in India?}

As we have seen, the plague was present in nineteenth-century India in the form of sporadic outbreaks in the western states and as an endemic threat in the northern and far northeastern foothills of the Himalayas. In addition, India imported plague through the port of Bombay, most likely from Hong Kong, in 1896 and became the country with the highest number of plague fatalities by far in the third plague pandemic. Between 1896 and 1921 an estimated twelve million Indians died of plague, compared to only three million plague fatalities in the rest of the world. ${ }^{40}$

For most of the half millennium before British rule in India, from approximately 1200 to 1760 , Muslims from central Asia ruled much of the northern plains and, to different degrees at different times, the center and other parts of the Indian subcontinent as well. These Muslim dynasties are referred to as the Delhi Sultanate (1210-1526) and the Mughal Empire (from 1526 to the British conquest in the latter half of the eighteenth and early nineteenth centuries). They generally maintained significant military, political, commercial, and religious ties with Transoxiana (the central Asian territory between the Caspian Sea and the Tibetan Plateau); the steppes beyond, from which they came; and the Middle East, the homeland of their faith and, in the earlier years, of the caliph from whom they claimed legitimacy. Both the Middle East and the western parts of central Asia suffered gravely from the initial wave of the second plague pandemic, the Black Death, during the fourteenth century. Before examining the evidence of plague in India during the second pandemic, it is worthwhile to review quickly the extent of the ties between India and the infected regions of western Asia in the fourteenth century.

40. On the third plague pandemic in India, see Echenberg, Plague Ports (n. 9), chap. 2 (p. 51 for fatalities); Rajnarayan Chandavarkar, "Plague Panic and Epidemic Politics in India, 1896-1914," in Epidemics and Ideas: Essays on the Historical Perception of Pestilence, ed. Terence Ranger and Paul Slack (Cambridge: Cambridge University Press, 1992), 203-40; David Arnold, Colonizing the Body: State Medicine and Epidemic Disease in Nineteenth-Century India (Berkeley: University of California Press, 1993), chap. 5; I. J. Catanach, "The 'Globalization' of Disease? India and the Plague," J. World Hist. 12, no. 1 (Spring 2001): 131-53; Ira Klein, "Plague, Policy and Popular Unrest in British India," Mod. Asian Stud. 22, no. 4 (1988): 723-55. 
In the period before, during, and following the Black Death in the West, north India was ruled from Delhi by two sultans of the Tughluq Dynasty, who both enjoyed unusually long reigns: Muhammad bin Tughluq (r. 1328-51) and Firuz Shah (r. 1351-88). The heartland of the Delhi Sultanate was the Doab, the plain between the Indus River and the Yamuna, the river on which Delhi is located and the westernmost major tributary of the Ganges River. Also included in Muslim India was the Sind, conquered by Arabs in the early eighth century and located at the mouth of the Indus River with ports on the Arabian Sea. At its greatest extent, around the second decade of the fourteenth century, the Delhi Sultanate exercised direct administrative control over additional territory in the eastern and central parts of the Indian subcontinent, including, of most importance for this discussion, large parts of Gujarat, whose ports on the Arabian Sea were largely populated by Muslim merchants. ${ }^{41}$ Thus the Delhi Sultanate was connected by sail to the Red Sea and the Persian Gulf and by caravan route to the northwest with the Mongol-dominated territories of Persia (the Ilkhanate), central Asia (the Chagatid khanate), and the steppes of southern Russia (the Golden Horde).

In the fourteenth century, when the Black Death was a menacing presence in Egypt, ceremonial embassies went back and forth regularly between Cairo and Delhi. The Turkic dynasties of Delhi sought recognition and legitimacy from the Abbasid caliphs, located initially in Baghdad and, after the Mongol conquest of Baghdad in 1258, in Cairo. In return the sultans inserted the caliph's name in the Friday sermons and on their coinage and paid an annual tribute. The Delhi chronicler Barani refers to one exchange of embassies initiated by Muhammad bin Tughluq around 1343. Firuz Shah received delegations from the Abbasid Caliph in 1353, 1362-63, and every year thereafter. ${ }^{42}$ The plague raged in Egypt from the fall of 1347 to February of 1349 and made many return visits thereafter. At least some visitors to Cairo, like Mujahid, the King of Yemen in 1351, carried the plague home from Cairo. ${ }^{43}$

The Delhi Sultanate maintained a vigorous trade with both the Middle East and central Asia during the plague years of the mid-fourteenth century. A major import for India was horses from Arabia, Persia, and central

41. Peter Jackson, The Delhi Sultanate: A Political and Military History (New York: Cambridge University Press, 1999), esp. chap. 10.

42. Sir H. M. Elliot, Tarikh-I-Firoz Shahi of Zia ud-Din Barni, ed. Prof John Dowson (1871; repr., Lahore, Pakistan: Chowk Minar Anarkali, 1974), 166-67; Jackson, Delhi Sultanate (n. 41), 3-4, 37, 162, 296.

43. Dols, Black Death in the Middle East (n. 8), 47, 154-55. 
Asia. Trade with central Asia was especially active between 1328-29, when the Chaghatid khan Tarmoshirin and the Delhi sultan Muhammad bin Tughluq both reduced commercial duties, and 1358, when the import of horses from the Russian steppes was interrupted by fighting among the khans of the Golden Horde. The port of Cambay in Gujarat was the principal focus of Indian maritime trade with the Persian Gulf. Through Cambay India exported grain and cotton cloth produced in Gujarat. The Persian Gulf was said to depend on India for food. Many luxury goods, for which the Delhi magnates were major consumers, were also exchanged or transshipped through Cambay. The forces of Sultan Ala al-Din Khalji initially invaded the coastal area of Gujarat in 1299-1300. Muhammad bin Tughluq spent three years in Gujarat and intensified administrative control there after 1349, at the height of the Black Death in the Middle East, which was Gujarat's trading partner across the Arabian Sea. ${ }^{44}$ Whether the Delhi Sultanate directly ruled Gujarat or not at any specific moment in the fourteenth century, we must imagine a continuous flow of merchants and merchandise among the Middle East, the port of Cambay, and the sultan's court in the plains of north India.

A final, major component of foreign trade during the Delhi Sultanate was the import of slaves. Most of the slaves appear to have been of Turkic origin and were purchased on the markets of Transoxiana (Samarqand, Bukhara, and Tirmid). Many were sold by the Mongols or driven into slavery by Mongol conquests. In India they became soldiers or servants of the amirs and sultans, who valued their loyalty and orthodox faith. Two of these Turkic slaves (called ghulams) even rose to be sultans themselves in the thirteenth century; their dynasties have been called the "slave dynasties." These central Asian slaves were joined by other refugees and immigrants from the same region who flooded into India, especially in periods of unrest in the Chagatid khanate, including the 1330s and the 1350s and 60s. ${ }^{45}$ Thus both stable and unstable conditions in the Mongol territories contributed to the movement of people between India and central Asia in the years surrounding the Black Death.

Yet, despite all this intercourse between the Delhi Sultanate and the plague-infected regions of the Middle East, central Asia, and the western steppes, there is no record of any significant epidemic in India during

44. Kanhaiya Lall Srivastava, The Position of Hindus under the Delhi Sultanate, 1206-1526 (New Delhi: Munshiram Manoharlal, 1980), 182-83, 186; Jackson, Delhi Sultanate (n. 41), 193, 197, 232-33, 252-53, 266, 315.

45. Jackson, Delhi Sultanate (n. 41), 4, 61-66, 41-43, 184-85, 233-34, 311-12. 
the years surrounding the Black Death in Europe and the Middle East. Diya-yi Barani (d. 1360-61) chronicled the years from 1260 through the reign of his close companion Muhammad bin Tughluq (r. 1328-51) and the first six years of Muhammad bin Tughluq's successor Firuz Shah (to 1357). ${ }^{46}$ In his work Barani refers to one significant epidemic that struck Muhammad bin Tughluq's army during a campaign in the Deccan in 1334-35. "The Sultan arrived at Arrangal," wrote Barani, "where cholera $(w a b a)$ was prevalent. Several nobles and many other persons died of it. The Sultan was also attacked." ${ }^{47}$ The Arabic word waba, translated here as "cholera," is a general term for an epidemic disease. It was occasionally used for cholera in India in the nineteenth century. The specific Arabic term for plague was ta'un. ${ }^{48}$ In the absence of any description of symptoms or report of the epidemic spreading beyond its place of origin, we must conclude that the epidemic that struck the Sultan's army in the central plateau of the Indian peninsula fifteen years before the Black Death is unlikely to have been plague.

Sham Siraj Afif, who served in the sultan's civil and revenue departments, chronicled the remainder of Firuz Shah's reign from 1357 to 1388. It was a period that was not only free from plague, but also, according to Afif, one of low prices, population growth, and prosperity. "There was not a single ruined village in the Doab region . . . and no land was without cultivation. Fifty two new settlements sprang up in the Doab region during his days. In regions other than Doab, the situation was the same." ${ }^{49}$ The contrast is striking with European accounts, such as that by the English cleric Henry Knighton, of abandoned fields and deserted villages in the same years. ${ }^{50}$ Indeed, the Indian subcontinent may have been the only part of Eurasia to have experienced steady population growth during the latter half of the fourteenth century (at least until the invasion of Temür the Lame at the end of the century).

The plague did finally make its appearance in India in the early seventeenth century, at a time when it was still making periodic reappearances in Europe and the Middle East. There is no mistaking the disease in this

46. Ibid., 49-51, 164. I follow Jackson's spelling of Barani's name rather than that of Sir H. M. Elliot's nineteenth-century translation.

47. Elliot, Tarikh-I-Firoz Shahi of Zia ud-din Barni (n. 42), 159.

48. Dols, Black Death in the Middle East (n. 8), 34; John MacPherson, M.D., Annals of Cholera: From the Earliest Periods to the Year 1817 (London: Ranken and Co., 1872), 6.

49. R. C. Jauhri, ed., Medieval India in Transition-Tarikh-i-Firoz Shahi: A First Hand Account (New Delhi: Sundeep Prakashan, 2001), vii-viii, 170-71.

50. Henry Knighton, in Horrox, Black Death (n. 2), 75-80. 
description provided by no less a witness than the Mughal emperor Jahangir. Jahangir describes his return with his army to the capital of Agra in January 1619, after a campaign of over five years in the Deccan: "At this time, again, it appeared from the reports of the loyal that the disease of the plague was prevalent in Agra, so that daily about 100 people, more or less, were dying of it. Under the armpits, or in the groin, or below the throat, buboes formed, and they died. This is the third year that it has raged in the cold weather, and disappeared in the commencement of the hot season." ${ }^{51}$ One could hardly wish for a clearer account of bubonic plague. Jahangir's description of the buboes (swelling of lymph glands) recalls medieval European images of St. Roch revealing the bubo on his upper thigh or the painting by Josse Lieferinxe, "St. Sebastian Interceding for the Plague Stricken," with its stricken gravedigger reaching for the bubo on his neck. ${ }^{52}$ The season of the epidemics corresponds to modern epidemiological knowledge of the optimal conditions for the adult rat flea: warm but not too hot, moist but not too wet. The biologist Graham Twigg identifies the ideal conditions for the rat flea as a temperature of $18.3^{\circ}$ to $29.4^{\circ} \mathrm{C}\left(65^{\circ}\right.$ to $\left.85^{\circ} \mathrm{F}\right)$ and a relative humidity of more than 70 percent. The eggs of the rat flea Xenopsylla cheopis can tolerate a broader temperature range, from $13^{\circ}$ to $34^{\circ} \mathrm{C}\left(55^{\circ}\right.$ to $\left.93^{\circ} \mathrm{F}\right) .^{53}$ In New Delhi (about 160 miles from Agra) this corresponds roughly with the temperature and humidity range from October to March; late spring is too dry and too hot for the rat flea, while the summer months, during the monsoon rains, are too hot and probably too humid. ${ }^{54}$ In the third pandemic plague outbreaks in India peaked in early spring, went into decline from May to July, and sometimes remounted to a second peak in the fall. ${ }^{55}$

Jahangir first noted the presence of plague in various parts of Hindustan in 1616. At that time, he reported, "It became known from men of great age and from old histories that this disease had never shown itself in this country (before). ${ }_{56}^{5}$ But plague would not have been new to the English merchant, Sir Thomas Roe, who represented his court at Agra from 1615 to 1619 . On October 29, 1616, Roe wrote, probably from the

51. Jahangir, The Tuzuk-I-Jahangiri; or, Memoirs of Jahangir, trans. Alexander Rogers, ed. Henry Beveridge (1909-14; repr., Delhi: Munshiram Manoharlal, 1968), II:65.

52. Christine M. Boeckl, Images of Plague and Pestilence: Iconography and Iconology (Kirksville, Mo.: Truman State University Press, 2000), 19-21.

53. Graham Twigg, The Black Death: A Biological Reappraisal (New York: Schocken Books, $1985), 114$.

54. The Weather Channel, 1995-2011, http://www.weather.com.

55. Klein, "Plague, Policy and Popular Unrest" (n. 40), 733.

56. Jahangir, Tuzuk-I-Jahangiri (n. 51), I:330. 
English factory at Surat (Gujarat), "I received news of a great plauge at Agra; so that I judgd it dangerous to send up the goods into an infected place from whence no comodytye could bee suffered to passe." A month later, on November 25, a caravan arrived from Agra with a Mr. Crowther, "of whom I received that the plauge was violent." Two months later Roe wrote, "I received from Agra that the plauge was fallen to 100 a day, and great hope of the clearning of the towne." 57

Accounts of the Indian plague epidemic of 1619 include one detail missing from all medieval accounts of the Black Death in Europe, the evidence of dying rodents. Mu'tamad Khan, Jahangir's court chronicler, wrote, "When [the epidemic] was about to break out, a mouse would rush out of its hole as if mad, and striking itself against the door and the walls of the house, would expire. If, immediately after this signal, the occupants left the house and went away to the jungle, their lives were saved; if otherwise, the inhabitants of the whole village would be swept away by the hand of death." ${ }^{58}$ Jahangir told another version of the same story:

The daughter of Asaf K . . . told me a strange and wonderful tale, and strongly insisted upon its truth. I write it on account of its strangeness. She said: "One day in the courtyard of the house I saw a mouse rising and falling in a distracted state. It was running about in every direction after the manner of drunkards, and did not know where to go. I said to one of my girls: 'Take it by the tail and throw it to the cat!' The cat was delighted, and jumped up from its place and seized it in its mouth, but immediately dropped it and showed disgust. By degrees an expression of pain and trouble showed itself on its face. The next day it was nearly dead, when it entered into my mind to give it a little treacle (tiryaq). When its mouth was opened, the palate and tongue appeared black. It passed three days in a state of misery, and on the fourth day came to its senses. After this the grain (dana) of the plague (a bubo) appeared in the girl, and from excess of temperature and increase of pain she had no rest. Her colour became changed-it was yellow inclining to black — and the fever was high ( tap muhriq gardid). The next day she vomited and had motions, and died. Seven or eight people in that household died in the same way, and so many were ill that I went to the garden from that lodging. Those who were ill died in the

57. Sir Thomas Roe, The Embassy of Sir Thomas Roe to India, 1615-1619, as Narrated in His Journal and Correspondence, ed. Sir William Foster (London: Oxford University Press, 1926), 268, 312, 336.

58. Mu'tamad Khan, Ikbal-Nama-i Jahangiri, in The History of India, as Told by Its Own Historians; The Muhammadan Period. The Posthumous Papers of the Late Sir H.M. Elliot, K. C.B., Edited Ev Continued by Professor John Dowson, M.R.A.S. (London: Trübner and Co., 1875; repr., New York: AMS Press, 1966), VI:406. 
garden, but in that place there were no buboes. In brief, in the space of eight or nine days seventeen people became travellers on the road of annihilation." ${ }^{59}$

The absence of any reference to dying rodents in medieval European and Middle Eastern chronicles of the Black Death, in contrast to their ubiquity in modern accounts from the third plague pandemic, ${ }^{60}$ is a striking anomaly. Several important books of the past twenty-five years have cited this absence as one reason to question whether the Black Death was caused by plague (i.e., Yersinia pestis) at all. ${ }^{61}$ Other historians, citing the similarity of clinical descriptions in the medieval chronicles and medical reports to modern plague and the absence of an alternative explanation for the Black Death, have suggested that the Black Death might have been plague transmitted in other ways, for example, through the air (primary pneumonic plague) or by human fleas. ${ }^{62}$ The reports from Jahangir's

59. Jahangir, Tuzuk-I-Jahangiri (n. 51), II:66-67.

60. For example, Albert Camus's novel La Peste (1947), which depicts a contemporary plague outbreak in Oran, Algeria.

61. See Twigg, Black Death (n. 53), 83; Scott and Duncan, Biology of Plagues (n. 37), 78; Samuel K. Cohn, Jr., The Black Death Transformed: Disease and Culture in Early Renaissance Europe (London: Arnold, 2002), 1. The plague skeptics have identified other important discrepancies between outbreaks of the "second plague pandemic" and those recorded by modern medical observers in the third pandemic, particularly the reports of the Indian Plague Commission from the early twentieth century. These discrepancies include, in addition to the premonitory dying off of rats, the exclusively warm-weather seasonality of the modern plague, a slower spread, lower population mortality, evidence of household case clustering rather than person-to-person transmission, the absence of acquired immunity, and, in the judgment of the plague skeptics, different symptoms (prominence of buboes in the modern epidemic and of more generally distributed pustules in the medieval and early modern epidemics).

62. Theilmann and Cate, "Plague of Plagues" (n. 37), 371-91; Lars Walløe, "Medieval and Modern Bubonic Plague: Some Clinical Continuities," in Nutton, Pestilential Complexities (n. 2), 59-73, esp. 69-73; Orent, Plague (n. 29), 3, 43-44, 121, 158, 167, 170. A primary pneumonic infection is acquired by inhaling plague bacteria adhering to droplets coughed out by someone with a pneumonic infection; a secondary pneumonic infection occurs when an infection acquired through a flea bite passes from the lymph system into the bloodstream and reaches the lungs. The symptoms are the same, but the mode of transmission is different.

Bolstering the traditional, symptomatic evidence of medieval plague have been various molecular studies reported in the past dozen years on the remains of plague victims from the first and second pandemics. Some of these studies claim to have identified fragments of Yersinia pestis DNA in the dental pulp of skeletons from mass graves identified by archaeologists with the first pandemic, the Black Death, and subsequent outbreaks of the second pandemic. See Michel Drancourt, Gerard Aboudharam, Michel Signoli, Olivier Dutour, and Didier Raoult, "Detection of 400-Year-Old Yersinia pestis DNA in Human Dental Pulp: An Approach to the Diagnosis of Ancient Septicemia," Proc. Nat. Acad. Sci. USA 95, no. 21 (October 13, 1998): 12637-40; Didier Raoult, Gérard Aboudharam, Eric Crubézy, Georges Larrouy, Bertrand Ludes, and Michel Drancourt, "Molecular Identification by 'Suicide 
court of dying mice (rats?) and the plague of 1619 may point to a different mode of transmission, different hosts, or different vectors in India's humid, semitropical climate than those found in temperate Europe and the arid Middle East.

Why did the Black Death not reach India in the fourteenth century in spite of the many ties between the Delhi Sultanate and the plague-infested regions of the Middle East and central Asia? William McNeill, acknowledging that there were "no special signs of any population crisis in India in the fourteenth century," offered one explanation. It will be recalled that McNeill believed that India, like central Africa, was an ancient focus of plague, while plague was a new presence in central Asia in the fourteenth century. In the ancient plague foci of India and Africa "habits and customs that restricted human plague to bearable proportions had presumably defined themselves. . . . Consequently, any additional exposure to Pasteurella pestis that may have filtered down from the North . . . would make little difference to the plague-experienced peoples of Africa and India." ${ }^{63}$ This explanation of India's escape from the Black Death ignores the fact that the plague foci in India in the nineteenth century, even if we

PCR' of Yersinia pestis as the Agent of Medieval Black Death," Proc. Nat. Acad. Sci. USA 97, no. 23 (November 7, 2000): 12800-803; M. Thomas P. Gilbert, Jon Cuccui, William White, Niels Lynnerup, Richard W. Titball, Alan Cooper, and Michael B. Prentice, "Absence of Yersinia pestis-Specific DNA in Human Teeth from Five European Excavations of Putative Plague Victims," Microbiology 150, no. 2 (February 2004): 341-54; Michel Drancourt and Didier Raoult, "Molecular Detection of Yersinia pestis in Dental Pulp," Microbiology 150, no. 2 (February 2004): 263-64; and I. Weichman and G. Grupe, "Detection of Yersinia pestis DNA in Two Early Medieval Skeletal Finds from Aschheim (Upper Bavaria, 6th Century A.D.)," Amer. J. Phys. Anthrop. 126 (January 2005): 48-55. Another group of studies has used different techniques to detect Yersinia pestis antigens in the remains from plague pits from the Black Death: Carsten M. Pusch, Lila Rahalison, Nikolaus Blin, Graeme J Nicholson, and Alfred Czarnetzki, "Yersinial F1 Antigen and the Cause of Black Death," Lancet Infect. Dis. 4 (August 2004): 484-85; Raffaella Bianucci, Lila Rahalison, Emma Rabino Massa, Alberto Peluso, Ezio Ferroglio, and Michel Signoli, "Technical Note: A Rapid Diagnostic Test Detects Plague in Ancient Human Remains: An Example of the Interaction between Archeological and Biological Approaches (Southeastern France, 16th-18th Centuries)," Amer. J. Phys. Anthrop. 136 (July 2008): 361-67; Haensch et al., "Distinct Clones" (n. 35).

As will become apparent in the rest of this article, I side with the majority view that Yersinia pestis was the causal agent of the Black Death, but with the important caveat that the mode of transmission of the medieval plague differed from the rat-to-rat flea-to-human sequence identified in the third pandemic in India in the first decade of the twentieth century.

63. McNeill, Plagues and Peoples (n. 7), 206. Pasteurella pestis is the former name for Yersinia pestis. The "habits and customs" referred to include avoidance of the meat of diseased rodents, isolation of patients, and abandonment of houses or villages overrun by diseased rodents. 
grant that they also existed in the fourteenth century, were located in the Himalayan foothills in the northeast and in Garhwal and Kumaon, closer to the north Indian plain but still beyond the reach of the Delhi Sultanate. The population centers of north India, and certainly the recently arrived Turkic rulers, could hardly have been "plague-experienced." Moreover, the plague did reach the population centers of north India in the early seventeenth century. Had the Indians of the Mughal era forgotten the habits and customs of plague prevention by then?

A second explanation for the absence of plague from fourteenthcentury India involves the flea vector that, based on the discoveries of the Indian Plague Commission in the early twentieth century, transmitted the plague bacillus from dying rat to susceptible human. The most efficient vector, it is generally agreed, is Xenopsylla cheopis, a species of flea native to Egypt. X. cheopis, like some other flea species carried by rats and humans, does not digest the Yersinia pestis bacilli it swallows with the blood of infected rats. Instead, the bacilli form a massive blockage in the flea's proventriculus (the upper part of the stomach), which the flea regurgitates into the next mammal it bites. ${ }^{64}$ This most efficient vector of concentrated plague bacilli is thought to have reached India from Egypt only in the late nineteenth century, probably in bales of cotton. $X$. cheopis prefers, as we noted above, a moderately warm and moist environment. The third plague pandemic did not spread to places like Mysore and Calcutta, where those conditions did not obtain and other flea species predominated..$^{65}$ Of course, this explanation also does not account for the presence of plague in India from the early seventeenth century, unless the Egyptian rat flea was introduced to India earlier than the late nineteenth century. This explanation also fails to explain why the Black Death could not have been transmitted to India by the human flea, as a growing number of scholars believe it was transmitted around Europe in the fourteenth century. ${ }^{66}$

A third possible explanation for the absence of plague from fourteenthcentury India is that sheer distance or physical barriers such as the cold

64. Albert Lawrence Borroughs, "Sylvatic Plague Studies: The Vector Efficiency of Nine Species of Fleas Compared with Xenopsylla cheopis," J. Hygiene 45, no. 3 (August 1947): 371-96.

65. Echenberg, Plague Ports (n. 9), 7, 70; Catanach, “'Globalization’ of Disease?” (n. 40), 138-43; Twigg, Black Death (n. 53), 127-28.

66. Orent, Plague (n. 29), 43-47, 121; Walløe, "Medieval and Modern Bubonic Plague" (n. 62), 71-72; Elisabeth Carniel, "Plague Today," in Nutton, Pestilential Complexities (n. 2), 115-22, esp. 117. 
temperature in the mountain passes separating India from central Asia might have blocked the transmission of the infected host or vector. This explanation, however, appears to run into the same problem as the previous two: Were there any improvements in sailing or changes in physical barriers between the fourteenth and seventeenth centuries sufficient to explain the plague's passage to India only in the later period? Might, for example, those English traders in Surat, newcomers from a plagueinfested land who sent home reports of the disease in India, have had something to do with its sudden appearance there?

To my mind the most likely explanation for India's avoidance of the Black Death was some combination of the distance and geographical barriers that separated the subcontinent from Europe, the Middle East, and central Asia, and the absence of appropriate vectors in her more tropical environment. If the most efficient vector, the Egyptian rat flea, in fact reached India by the early seventeenth century, it might have picked up the pathogen, Yersinia pestis, either from infected rats carried to India by Arab or European trading vessels that had stopped in the Middle East or from infected native rodents encountered by Mughal military expansion into the Himalayan foothills, and thus set off the plague described by Jahangir and his contemporaries.

\section{Was the Black Death in China?}

The third plague pandemic in China comprised two distinct epidemics, as the "plague fighter" Wu Lien-teh pointed out. There was a northern epidemic centered in Manchuria and a southern epidemic originating in Yunnan. The pneumonic plague was more conspicuous in the north, while the southern plague was predominantly bubonic. Northern outbreaks began in the fall and lasted through the winter; outbreaks in semitropical south China began in spring and ended in late summer. The northern plague arose from infected steppe marmots known as tarabagans and was transmitted from person to person by coughing; the southern plague was carried by rats and transmitted to people by the rat flea Xenopsylla cheopis. When Wu wrote in 1936, the southern plague was on the wane, but local outbreaks of northern plague still occurred every year in Shaanxi, Shanxi, and southwestern Manchuria. Both forms had a high mortality, and both were caused by the bacillus Yersinia pestis. ${ }^{67}$ Otherwise the northern plague

67. Wu Lien-teh, J. W. H. Chun, R. Pollitzer, and C. Y. Wu, Plague: A Manual for Medical and Public Health Workers (Shanghai Station, China: Weishengshu National Quarantine Service, 1936), 42-43. 
and the southern plague in China were connected only coincidentally in the third pandemic.

The earliest record Dr. Wu found of plague among the tarabagans of Transbaikalia and Outer Mongolia (across the border from Manchuria) was the memoir of a Russian hunter from 1856-63 who also reported the spread of the plague from the animals to humans. Native hunters already knew to avoid sick tarabagans. The first medical reports of plague in the region were by two Russian doctors in 1895 , and the first bacteriological confirmation of plague in humans came in $1905,{ }^{68}$ a decade after the bacillus was identified in Hong Kong and five years before the major outbreak of pneumonic plague that took at least 52,462 lives in Manchuria in the winter of $1910-11 .^{69}$

Opinion is divided on how the southern plague reached Yunnan. Robert Koch thought it came from Tibet; others believed it came from Burma. Both regions were connected via caravan routes and the Salween River with Yunnan. ${ }^{70}$ We saw above that William McNeill suggested that Yunnan was an ancient focus from which the Mongols spread plague to the steppes in the thirteenth century. But there is no direct evidence at this point for the presence of plague in Yunnan before the eighteenth century. From 1772 to 1830 there are frequent references to epidemics in the local gazetteers, first in western Yunnan adjoining Burma in the last quarter of the eighteenth century, then expanding to eastern Yunnan and the provincial capital, Kunming, in the first quarter of the nineteenth century. What ties these reported epidemics to plague are other sourcesa Chinese explorer and a poet in the eighteenth century, the memorial of a provincial education official in the nineteenth century-that describe the dying off of rats prior to the epidemics and the characteristic human symptoms, buboes and spitting of blood (associated with pneumonic plague). The poet Hung Liang-chi (1736-1809) wrote of the rats,

In 1792 at Chaochow, Yunnan, rats were seen in day-time. They vomited some blood and fell dead. Human beings inhaling the odour of the dead rats rapidly succumbed. Shih Tao-nan (1765-1792), a native of Chaochow and son of the magistrate of Wangchiang, Anwhei-a young man of extraordinary talent—composed a poem Tien Yü Chi, a part of which entitled "Death of

68. Wu, "Original Home of Plague" (n. 22), 294-95.

69. Wu, Plague Fighter (n. 22), 33.

70. Carol Benedict, Bubonic Plague in Nineteenth-Century China (Stanford, Calif.: Stanford University Press, 1996), 28-29; Wu, "Original Home of Plague" (n. 22), 296. 
Rats" vividly described the calamity. The author himself died of plague almost immediately after. ${ }^{71}$

This passage is the earliest reference I am aware of in the Chinese sources to a premonitory rodent epizootic. In this respect, the plague of Yunnan in 1792, like that of Agra in 1619, seems more like a predecessor of the tropical and semitropical third plague pandemic, of Himalayan origin, than a late manifestation of the second pandemic, rooted in the steppes, in which the rats were so conspicuously absent from the sources. Following its emergence in western Yunnan in the late eighteenth century and its spread to the eastern part of the province in the early nineteenth century the plague made its slow way between 1860 and 1894 from Yunnan eastward to the coast at Canton and Hong Kong carried by Rattus flavipectus (the yellow-chested rat), Xenopsylla cheopis (the rat flea), and the merchants, smugglers, soldiers, refugees, and bandits who peopled the roads of Yunnan, Guangxi, and Guangdong provinces and the junks and steamboats of the Gulf of Tonkin and the South China Sea. ${ }^{72}$

Before the appearance of the two distinct forms of plague in the eighteenth and nineteenth centuries, China offers two important types of evidence about epidemics not available in India in the same period. These are regular notations of epidemics in dynastic histories, court annals, and local gazetteers, on the one hand, and census counts of population (or, at least, of households), on the other.

The notation of epidemics in official records goes back at least to the Tang Dynasty (618-907 CE). The records consisted of dynastic histories compiled in the next dynasty and Monographs on the Five Elements (Wuhsing (hih) incorporated into the dynastic histories. In these records epidemic outbreaks were "listed together with floods, droughts, unusual climatic phenomena, astronomical portents such as eclipses and comets, earthquakes, prodigies and monstrous births, as phenomena that might according to convention be interpreted as having some significance in relation to human affairs." ${ }^{\prime 3}$ From the Tang Dynasty epidemics were

71. Quoted in Wong K. Chimin and Wu Lien-teh, History of Chinese Medicine: Being a Chronicle of Medical Happenings in China from Ancient Times to the Present Period (2nd ed. 1936; repr., Taipei: Southern Materials Center, 1985), 507. I omitted from this quotation the Chinese characters parenthetically inserted after several names.

72. Benedict, Bubonic Plague in Nineteenth-Century China (n. 70), chaps. 1-2; Wu, "Original Home of Plague” (n. 22), 293; Echenberg, Plague Ports (n. 9), chap. 1.

73. Denis Twitchett, "Population and Pestilence in T'ang China," in Studia Sino-Mongolica: Festscrift für Herbert Franke, ed. Wolfgang Bauer (Wiesbaden, Germany: Franz Steiner, 1979), 35-68, quotation on 40 . 
generally identified simply as $i$ ("epidemic") or ta-i ("great epidemic")—yi or dayi in pinyin - with no further identification of the specific disease entity (malaria, cholera, plague, etc.) or their signs and symptoms. The record also showed the year in which the outbreak occurred and some indication of the province or provinces affected. The listing of natural disasters was compiled by the Historiographer's Office based on reports from the Board of Finance, which collected the information because of its impact on tax revenues and remissions. ${ }^{74}$

The primary motivation for collecting this information was what the historian Shigehisa Kuriyama refers to as "the cosmo-political interpretation, according to which epidemics, along with droughts and other catastrophes, were triggered by transgressions against the will of Heaven by the Emperor, the Son of Heaven." ${ }^{75}$ But historians of the Tang Dynasty and of the Northern Song Dynasty (960-1127) have not found any correlation between reported epidemics and significant political events. ${ }^{76}$ This suggests these reports were more or less accurate reports of epidemic outbreaks. Accurate, but not complete. The annalistic reports tended to emphasize epidemics in and around the capital. ${ }^{77}$

Although historians have speculated about the disease entities responsible for specific outbreaks, this remains a hazardous enterprise. ${ }^{78 \text { "Chinese }}$ chronicles," declared historian Carol Benedict, "provide little evidence on which to base a firm conclusion that any pre-Qing [i.e., before 1644] epidemic was in fact caused by Yersinia pestis." ${ }^{\prime 79}$ Indeed, the current Chinese word for "plague," shuyi ("rat epidemic"), did not appear until the nineteenth century, although some historians have suggested there were earlier designations for the disease. ${ }^{80}$ The underlying problem is a differ-

74. Ibid., 40-42.

75. Shigehisa Kuriyama, "Epidemics, Weather, and Contagion in Traditional Chinese Medicine," in Contagion: Perspectives from Pre-Modern Societies, ed. Lawrence I. Conrad and Dominik Wujastyk (Burlington, Vt.: Ashgate, 2000), 3-22, quotation on 4.

76. Twitchett, "Population and Pestilence in Tang China" (n. 73), 41; Asaf Goldschmidt, The Evolution of Chinese Medicine: Song Dynasty, 960-1200 (New York: Routledge, 2009), 83-84.

77. Goldschmidt, Evolution of Chinese Medicine (n. 76), 82.

78. Twitchett, "Population and Pestilence in Tang China" (n. 73), 35-68; Helen Dunstan, "The Late Ming Epidemics: A Preliminary Survey," Ch'ing-Shih wen-t'i 3, no. 3 (November 1975): 1-59. Dunstan draws on local gazetteers, which began to become available in the Ming Dynasty.

79. Benedict, Bubonic Plague in Nineteenth-Century China (n. 70), 11.

80. Dong Lu, Xi Ma, and François Thann, Les maux épidémiques dans l'empire chinois (Paris: Éditions L'Harmattan, 1995), 55-59. The authors argue that a disease outbreak identified in the northern Jin Dynasty (1115-1234) as the "epidemic of the large head" must refer to the inflamed lymphatic ganglia of the neck in plague. 
ent conception of disease in Chinese medicine. To quote Benedict again, "Chinese doctors do not think of the body as a stable form or of illness as an identifiable entity; rather, they view both physiology and pathology as constantly evolving processes." 11 This does not mean that Chinese doctors did not take notice of clinical signs and symptoms, but only that they treated constantly changing syndromes rather than specific disease entities. Sometimes we may speculate with some confidence about the specific disease responsible for an epidemic outbreak in China based on a medical description of signs and symptoms. But such descriptions do not generally appear in the official chronicles.

A second, indirect source for the timing of epidemics in premodern China is the censuses compiled by the central government. While the Chinese did view population movements as indicators of good or bad rule, the primary purposes for which population data were collected were taxation and military and labor conscription. Beginning in the Tang Dynasty (618-907) the emphasis was on counting households rather than individuals ("doors" rather than "mouths" in the Chinese terminology) for the purpose of assessing land taxes. Changes in the number of households or individuals from one census to another did not necessarily reflect fluctuations in population. Often census-to-census differences are due to changes in administrative efficiency or methods (for example, the inclusion or omission of people outside households, such as slaves, monks, and vagabonds), an expansion or contraction of territory under central control, or changes in the ratio of individuals to households (a particularly volatile ratio in the Song Dynasty). ${ }^{82}$ The Yuan Dynasty, in power during the years when the Black Death first reached Europe and the Middle East, was especially intent on classifying and registering subjects by ethnic status and occupation and less interested in counting households and individuals. ${ }^{83}$

The century of Mongol rule of China known as the Yuan Dynasty (1271-1368) can be divided into two periods. The first period was marked by a long process of Yuan disengagement from the politics of the steppes and the disintegration of the larger Mongol Empire. The qaghan or Great

81. Benedict, Bubonic Plague in Nineteenth-Century China (n. 70), 101.

82. Twitchett, "Population and Pestilence in Tang China" (n. 73), 37-39; Michel Cartier and Pierre-Étienne Will, "Démographie et institutions en Chine: contribution à l'analyse des recensements de l'époque impériale (2 ap. J.-C.- 1750)," in Annales de démographie historique (1971): 161-245, esp. 162-64 and 194.

83. Frederick W. Mote, "Chinese Society under Mongol Rule, 1215-1368," in The Cambridge History of China, vol. 6, Alien Regimes and Border States, 907-1368, ed. Herbert Franke and Denis Twitchett (New York: Cambridge University Press, 1994), 616-64, esp. 618. 
Khan Qubilai (died 1294) began the process in 1260, before the formal declaration of the Yuan Dynasty, when he transferred the capital of the Mongol Empire from Qaraqorum, Mongolia, to Ta-tu (modern Beijing) to be nearer his own part of Chinggis Khan's inheritance, northern China, and the southern part of China that he was to conquer over the next two decades. Qubilai, a grandson of Chinggis, and his immediate successors engaged in perpetual warfare with and political meddling in the affairs of two other branches of the family, the descendants of Chinggis's sons and Qubilai's uncles Chaghatai and Ögödei, who governed the territory between the Caspian Sea and the western frontiers of China and Mongolia. These struggles wound down in the early years of the fourteenth century as the Yuan Dynasty incorporated Mongolia into the Chinese administrative system and the central Asian khans converted to Islam and lost interest in the now mostly empty title of qaghan. The Emperor Qoshila, whose base was in Mongolia and who enjoyed the support of the Chaghatid ruler, was the last link of Yuan China with the idea of the Mongol Empire. He was assassinated in 1329 after six months of rule.

Two weak emperors, Tugh Temür (r. 1329-32) and Toghon Temür (r. 1332-68), presided over the chaotic remaining years of Mongol rule in China. This forty-year period was marked by bitter factional struggles for control of the bureaucracy; rebellions in south China in 1337-38; uprisings, banditry, famine, and devastating floods in the 1340 s, most notably a flood of the Yellow River in the summer of 1344 when the river shifted its course from south of the Shandong Peninsula partially to the north and partially into the Grand Canal, cutting off the main inland supply route for grain from the Yangzi delta to the capital; coastal piracy beginning about the same time and creating obstacles to maritime transport of grain; the Red Turban Rebellion in the early 1350s; and the complete collapse of central authority from the mid-1350s as the future Ming Dynasty took shape in the south and the whole country fell under the authority of regional warlords. ${ }^{84}$

Epidemics were certainly part of the crescendo of disasters that marked, as the Chinese might say, the withdrawal of the Mandate of Heaven from the Yuan Dynasty. In identifying the great epidemics of the fourteenth century, I rely on two English versions of a list compiled in the eighteenth century from earlier dynastic histories and local gazetteers for an imperial encyclopedia. One version was translated and edited by Prof. Joseph $\mathrm{H}$. Cha for William McNeill's book, Plagues and Peoples, in which it appears as

84. This summary is based on John W. Dardess, Conquerors and Confucians: Aspects of Political Change in Late Yuan China (New York: Columbia University Press, 1973). 
an appendix. ${ }^{85}$ The other was prepared in the Chinese Imperial Maritime Customs Service (an institution created and staffed by the Western powers to collect Chinese customs) between 1871 and 1882 and published in two forms in 1884 and $1936 .{ }^{86}$ Even the Chinese source for these lists is far from perfect, as it was compiled centuries after the events from provincial summaries of local events recorded unevenly in different parts of the country. ${ }^{87}$

William McNeill, it will be recalled, believed that Mongol horsemen had encountered plague in their initial invasion of Yunnan in 1252-53 and carried it back to the steppes. The problem with this hypothesis, he acknowledged, was that Chinese records do not show any unusual epidemic until $1331 .{ }^{88}$ In that year, according to Cha's list, an epidemic in the northeastern province of Hebei killed nine-tenths of the population. The Customs Service also lists an epidemic that year in which "nine-tenths of the people perished" but locates it in the south central province of Hunan. Both editors relocated place names in modern provinces. ${ }^{89}$ One has to wonder if one of these sources misidentified the province with 90 percent mortality (surely an exaggerated figure). The Customs Service list shows this epidemic persisting and spreading over several years. The entry for 1333 observes, "This pestilence, while it continued during this and the succeeding year, overspread China, causing a mortality estimated at thirteen millions of persons." Both lists refer to another round of epidemics in the southeast and northeast coastal provinces of Fujian and Shandong in 1344-46, characterized by the Customs Service as a "great pestilence." The epidemics return in the 1350 s, raging in one or more provinces almost every year. This round begins in the north-central province of Shanxi, northeastern Hebei, and central-coastal Jiangsu in 1351-52, according to Cha, in the first month of 1352 in Shanxi, according to the Customs Service. The Customs Service characterizes the 1352 epidemic as "a great pestilence" and counts 900,000 deaths. The epidemic returns and spreads

85. McNeill, Plagues and Peoples (n. 7), 297-306.

86. "Appendix. XXXIV. Epidemics," in An Epitome of the Reports of the Medical Officers to the Chinese Imperial Maritime Customs Service, from 1871 to 1882, ed. Surgeon-General C. A. Gordon, M.D., C.B. (London: Baillière, Tindall, \& Cox, 1884), 325-59. The same list, without interpolated references to Western epidemics, appears in Wu et al., Plague (n. 67), 43-51.

87. I am grateful to an anonymous reader of this article for these cautions as well as other insights.

88. McNeill, Plagues and Peoples (n. 7), 173.

89. I have substituted the pinyin transliteration for the Wade-Giles transliteration of modern provinces. 
in 1353 and 1354, killing "more than two thirds of the population" in part of Shanxi in 1353 and "six or seven out of ten of the population" in part of the central Yangzi province of Hubei the next year, according to Cha. The Customs Service also notes "great pestilence" and "great plague" in various provinces in 1353 and 1354, reaching the capital in the latter year. Cha lists additional epidemics in various provinces every year between 1356 and 1360; in Shanxi and Hebei in 1358 "over 200,000 died." The Customs Service lists "great pestilences" every year from 1356 to 1362 in various provinces.

To summarize, the admittedly imperfect summary of Chinese records shows three rounds of epidemics in the last forty years of the Yuan Dynasty. The first round occurred in the years 1331-34, spreading out from one or both of the widely separated provinces of Hebei and Hunan. The second round occurred in 1344-46 in coastal Fujian and Shandong, where a massive flood and displacement of the Yellow River also occurred in the summer of 1344 . The third round raged throughout the 1350s and spread over most of northern and central China in the midst of widespread rebellion. ${ }^{90}$ In all three rounds mortality was exceptionally high, at least in some localities. ${ }^{91}$ We have no information about the signs, symptoms, or course of the disease or diseases responsible for the epidemics.

All discussions of the Chinese population during the Yuan Dynasty depict a huge loss. The consensus estimates are 120 million (combining Southern Song Dynasty in the south and Chin Dynasty in the north)

90. Timothy Brook also identifies three severe epidemics of the late Yuan period: in 1344-45, 1356-60, and 1362. In omitting reference to epidemics in 1331-34, Brook makes it less likely that the Black Death of Europe and the Middle East, beginning in 1346, could have originated in China. Timothy Brook, The Troubled Empire: China in the Yuan and Ming Dynasties (Cambridge, Mass.: Harvard University Press, 2010), 64-65.

91. Traditional estimates of mortality for the Black Death in Europe run from one-quarter to one-third overall, with some cities and regions bypassed completely and some cities registering over 50 percent mortality. See the cautious discussion of this topic in Jean-Noël Biraben, Les hommes et la peste en France et dans les pays européens et méditerranéens, vol. 1, La peste dans l'histoire (Paris: Mouton, 1975), chap. 4. The extremes in the discussion of population mortality in the Black Death are represented by the biologist J. F. D. Shrewsbury, who insisted that plague was primarily an urban disease that could not have killed more than 5 percent of the population of the British Isles in the Black Death, and the historian Ole J. Benedictow, who claimed that the Black Death attacked every part of Europe with the exception of Iceland and Finland, caused even greater mortality in rural areas than in towns and cities, and killed approximately 60 percent of the population. See J. F. D. Shrewsbury, A History of Bubonic Plague in the British Isles (Cambridge, UK: Cambridge University Press, 1970), 36, 122-23; Benedictow, Black Death (n. 32), chap. 24 and part IV. I think most historians today would reject Shrewsbury's estimate as far too low and Benedictow's as somewhat high. 
around 1200, on the eve of the Mongol invasion, and half that number, 60 million, around 1390, shortly after the Ming Dynasty replaced the Yuan Dynasty. ${ }^{92}$ The trouble with this comparison of the Chinese population before and after the Yuan Dynasty is that it runs together the population loss due to the Mongol conquest of China in the thirteenth century with the population loss due to the collapse of Mongol rule, rebellions, floods, and epidemics in the fourteenth century.

Frederick Mote offers a somewhat more nuanced, three-point comparison of population in China over the period of the Yuan Dynasty that segregates the losses of the thirteenth and fourteenth centuries. Combining his figures for the Southern Song census of south China in 1223 and the Chin census of North China in 1207 yields a pre-Mongol total of 21.0 million households and 116.5 million population. This compares with 13.9 million households and 58.8 million population in Qubilai's census of 1290, considered the most reliable of Mongol counts. Finally, Mote reports the figures for the early Ming census of 1393: 10.7 million households and 60.5 million population. ${ }^{93}$ Focusing only on households, which are considered much more reliable than the census of "mouths," 94 it appears that China's population plummeted by as much as one-third in the course of the Mongol invasions of the thirteenth century, then may have fallen again by close to one-quarter in the epidemics, floods, and rebellions of the fourteenth century.

But China's population loss in the fourteenth century could have been much greater than one-quarter for two reasons. First, the Mongol enumerations have been characterized as "very incomplete," especially in northern China.${ }^{95}$ If this is the case and the 1290 population was actually greater than the registered figures of 13.9 million households and 58.8 million population, that would imply a larger portion of the total Mongol population loss attributable to the floods, rebellions, and epidemics of the fourteenth century. Secondly, it has been suggested that instead of declining steadily throughout the period of Mongol rule, China's population recovered to some degree in the relatively peaceful years following

92. Angela Ki Che Leung, "Diseases of the Premodern Period in China," in The Cambridge World History of Human Disease, ed. Kenneth F. Kiple (Cambridge, UK: Cambridge University Press, 1993), 354-62, esp. 357; John D. Durand, "The Population Statistics of China, A.D. 2-1953,” Popul. Stud. 13, no. 3 (March 1960): 209-56, esp. 249.

93. Mote, "Chinese Society under Mongol Rule" (n. 83), 618-21.

94. Cartier and Will, "Démographie et institutions en Chine” (n. 82), 193-94.

95. Durand, "Population Statistics of China" (n. 92), 229-33. 
the 1290 census, only to collapse again after $1340 .{ }^{96}$ Taken together, these two considerations suggest that China's population loss in the last thirty to forty years of Mongol rule could easily have matched or exceeded the traditional estimate of one-quarter to one-third population loss in Europe due to the Black Death.

Within China the greatest population loss in the Yuan period appears to have occurred in the northeastern provinces of Hebei and Shandong. According to Mote, the number of households in this region fell from 3.3 million in 1207 to 1.1 million in 1393 , a startling two-thirds loss. ${ }^{97}$ While much of this loss could be attributed to northern Chinese who fled to the south to escape the initial Mongol invasion and the conversion of farmland to grazing in the thirteenth century, in the fourteenth century the northeast was more affected than other regions by fighting around the capital, the flood and displacement of the Yellow River, disruptions in rice shipments from the Yangzi delta, and repeated epidemics. On the other hand, a recent study of the southern Yangzi delta (southern Jiangsu and northern Zhejiang provinces today) found that population was growing there between 1210 and 1290, continued to grow until the mid-1350s, and then fell by less than 10 percent by $1381 .^{98}$

What we know, then, is that major, highly lethal epidemics afflicted China in the 1330s-50s and undoubtedly contributed to a catastrophic population collapse that began in the thirteenth century and continued, or perhaps rebounded, in the mid-fourteenth century. Although we know nothing of the clinical details of the disease or diseases behind the epidemics, we do know that they began in the northeast (Hebei and Shandong) and spread down the coast and inland to the central provinces. We hear only scant references to these epidemics in the south and none in the southwest or west. ${ }^{99}$ Of course, that may be because those areas

96. Article by Ch'iu Shu-shen and Wang T'ing in 1983 in Chinese, summarized and discussed by Mote, "Chinese Society under Mongol Rule" (n. 83), $622 n 8$.

97. Mote, "Chinese Society under Mongol Rule" (n. 83), 621; Cartier and Will, "Démographie et institutions en Chine" (n. 82), 198.

98. Li Bozhong, "Was There a 'Fourteenth-Century Turning Point'? Population, Land, Technology, and Farm Management," in The Song-Yuan-Ming Transition in Chinese History, ed. Paul Jakov Smith and Richard von Glahn (Cambridge, Mass.: Harvard University Press, 2003), 135-75, esp. 137-43.

99. The only references to southern provinces affected by the epidemics are one mention by Cha of an epidemic of 1354 in Guangdong and Guangxi and references by Cha and the Customs Service to an epidemic in 1359 in Guangdong. There are no mentions in either source of epidemics during this period in the southwestern and western provinces of Yunnan, Sichuan, Guizhou, Gansu, or Shaanxi. 
were remote from the capital and sparsely populated compared to the northeastern and central provinces. If the disease afflicting China in the mid-fourteenth century was the plague, which was ravaging the Middle East and Europe from 1347 onward, it probably entered China from the Mongolian steppes north of Hebei and not from the Yunnan focus in the far southwest.

The earliest fairly promising clinical description of the plague that I have found in China dates from the second of two Ming-era epidemics that have been characterized as the most widespread and lethal in recorded Chinese history: $1586-89$ and $1639-44 .{ }^{100}$ This report comes from a local gazetteer from Lu-an, Shanxi, in 1644: "In the autumn there was a great epidemic. The victim first developed a hard lump below the armpits or between the thighs or else coughed thin blood and died before they had time to take medicine. Even friends and relations did not dare to ask after the sick or come with their condolences. There were whole families wiped out with none to bury them." 101 The second sentence of this account seems to point directly to the two most common forms of plague, the bubonic and pneumonic. Shanxi, in north-central China bordering on Inner Mongolia, was a focus of endemic plague infection in the early twentieth century and the site of a plague epidemic in 1917-18. Cha's list of epidemics in China notes, for 1644, epidemics in Shanxi, Jiangsu, and Inner Mongolia. Like the local gazetteer, the Customs Service list refers to a "Great pestilence in Lu-an," Shanxi; it adds, "Those attacked had hard lumps grow on the neck or arm, like clotted blood. Whole families perished. In some cases the victims spat blood suddenly, and expired."102 Thus, the 1644 epidemic sounds like a northern epidemic, similar to those of the mid-fourteenth century, but now enhanced by clinical descriptions pointing to bubonic and secondary pneumonic plague.

Some historians of diseases in China nevertheless argue that the first epidemic in China that can confidently be identified as plague began in Yunnan in 1792. This epidemic, discussed above, spread from Yunnan to

100. Mark Elvin, The Pattern of the Chinese Past: A Social and Economic Interpretation (Stanford, Calif.: Stanford University Press, 1973), 310-11. Wu Lien-Teh quotes three clinical descriptions of deadly "bubonic diseases" from China in the seventh century CE, at the time of the first plague pandemic. None of the three refer to the specific site of the buboes or to pneumonic symptoms. Wu's historical sketch of the plague in China then skips to the late eighteenth century, omitting any reference to the second pandemic. Wu et al., Plague (n. 67), 11-12.

101. Quoted in Dunstan, "Late Ming Epidemics" (n. 78), 19.

102. See notes 85 and 86 above. 
Guangxi, Guangdong, and up the coast to Fujian and northern China. ${ }^{103}$ The 1792 epidemic, associated with a rat epizootic, is clearly a southern plague and a precursor of the third plague pandemic rather than a late outbreak of the second.

It would be easier to explain the absence of the Black Death of the fourteenth century from China than from India. China was farther from the Middle East and Europe than India and had fewer commercial, military, religious, or political ties with the regions where we know the plague was rampant. Nevertheless, the case for the Black Death in China seems stronger than that for India. China experienced major epidemics from the 1330 s to the 1350 s with devastating population loss, while India was free of either. The fourteenth-century epidemics in China began in the northeast and spread from there to the coast and center of the country, but appear not to have reached the southwest, which is to say, the Yunnan plague focus. This geographic pattern of infection suggests the pathogen most likely came from the steppes to the north, where we know the plague was present by the late nineteenth century.

On the other hand, there are several reasons for questioning a plague diagnosis for China in the fourteenth century. First, the epidemics of fourteenth-century China, devastating as they were, do not appear to have spread over the entire inhabited territory of the Middle Kingdom as the Black Death did in Europe. ${ }^{104}$ Given the fact that plague would have been new to China, or at least had not visited it for centuries, as was the case in Europe, and thus would have represented a "virgin-territory epidemic," and given the relatively dense population and integrated economy and polity of China, a territorial plague pandemic spreading in a determinate direction would be more probable than the sporadic, provincial epidemic outbreaks described in the annalistic records.

A second reason for questioning the presence of plague in fourteenthcentury China is the absence of any clinical description of plague in contemporary records of that very literate civilization. Elisabeth Carniel, a medical researcher at the Pasteur Institute, points out that the symptoms of plague, although varied according to the form it takes (bubonic or pneumonic), are striking and distinctive enough to be readily recognized by laymen living in endemic areas. ${ }^{105}$ If not treated immediately by

103. Leung, "Diseases of the Premodern Period in China" (n. 92), 355.

104. For descriptions of the spread of the Black Death around Europe, see Biraben, Les hommes et la peste (n. 91), I:71-85; Benedictow, Black Death (n. 32), part II.

105. Carniel, "Plague Today" (n. 66), 118-19, 121-22. 
modern antibiotics, those symptoms are the rapid rise in temperature, quickening of pulse, and general prostration, the appearance of a sizeable, very painful swelling or bubo in the lymph node closest to the site of the flea bite (generally around the groin, thigh, underarm, or neck), coughing or spitting of bloody sputum if the infection spreads into the lungs (secondary pneumonic plague), high lethality and rapid death (case mortality is nearly 100 percent within less than three days in the case of pneumonic infection, 40-70 percent in three to five days for the simple bubonic infection).${ }^{106}$ Laymen in fourteenth-century Europe and seventeenth-century India and China readily identified these symptoms. If no one in fourteenth-century India or China took note of these terrifying symptoms, the explanation may be that these societies did not experience plague at that time.

A third reason for questioning the presence of plague in fourteenthcentury China is the problem of explaining how it got there from some indeterminate place of origin in the Eurasian steppes at about the same time that it also reached the Crimea, some 5,000-6,000 miles away as the crow flies. The biologist Graham Twigg pointed out that the plague in South Africa during the third pandemic traveled at a sluggish rate of 8-12 miles per year when transmitted to one another by domestic rodents and about 20 miles per year among wild rodents. At either rate it would have taken centuries for the plague to have spread from a single focus in Asia to both extremities of the Silk Road. By contrast, the Black Death spread overland through Europe at a brisk rate of 1.5-5 miles per day, a rate that would shorten the trip across Asia to three to four years. For Twigg the contrast between these two rates was proof that the Black Death was not caused by Yersinia pestis. ${ }^{107}$ Wendy Orent suggested a different explanation: "The Black Death could spread as fast as people could travel, because it was borne by human beings." 108 Orent took the controversial position that the human flea (Pulex irritans) transmitted the Black Death from person to person. Ole Benedictow, who accepts the traditional path of transmission for the Black Death via rats and rat fleas, still estimates a pace of 0.5-2.0 kilometers (0.3-1.2 miles) per day for its spread through Europe carried by infected people (who could not have traveled far before succumbing to their illness) bearing infective rat fleas or by infective rat fleas lodged

106. Ibid., 118-19.

107. Twigg, Black Death (n. 53), 139.

108. Orent, Plague (n. 29), 118. 
in clothing or merchandise. ${ }^{109}$ While such transmission seems plausible in agricultural and commercial Europe of the fourteenth century, with its network of cities, market towns, agricultural villages, and hamlets, each with its grain stores and domestic rat colonies, it seems far less plausible across 5,000 miles of arid grassland thinly populated by migratory pastoralists and caravan towns often separated from one another by weeks of travel. Far easier to believe, with John Norris and Ole Benedictow, "the principle of proximate origin" (in Benedictow's phrase), that the Black Death in Europe and the Middle East began in the plague focus closest to where it was first observed in the Crimea and never reached China. ${ }^{110}$

If the epidemics of fourteenth-century China were not plague, what were they? Because of the absence of any clinical descriptions, the identification of alternatives is as difficult as the identification of plague. Ann Bowman Jannetta believes that the most prominent epidemic diseases of early modern Japan, before sustained contact with Westerners, were smallpox, measles, cholera, and dysentery. Isolated Tokugawa Japan was free of plague and typhus before the nineteenth century. ${ }^{111}$ Angela Ki Che Leung believes that the major diseases of China before the sixteenth century and the arrival of Europeans by sea were smallpox, pulmonary diseases (principally pneumonia and tuberculosis), malarial and other fevers (including probably typhoid and typhus, possibly meningitis, cerebrospinal fever, and influenza), dysentery, "and possibly plague." 112 The social and environmental conditions of fourteenth-century China, including flooding, warfare, and the famine and displacement they caused, were favorable for the development of malaria, of gastrointestinal disorders like typhoid fever and dysentery, and of crowd diseases like typhus. ${ }^{113}$ The epidemics and population loss, we saw, were most prominent in northern China where flooding and fighting were also concentrated.

When the symptoms of plague were finally described unmistakably in India and China in the seventeenth century, the disease behaved differently than it did in fourteenth-century Europe. In seventeenth-century India and China the human epidemic was preceded by conspicuous rat

109. Benedictow, Black Death (n. 32), 229-31. After the appearance of infective rat fleas in an uninfected locale, a delay of two to three weeks ensued while the imported, infective rat fleas transmitted the pathogen to a hitherto uninfected rat colony, the rats of that colony died off, their fleas transferred to the human population, and the plague incubated in the first human patients. See ibid., 18.

110. Ibid., 50. For a similar argument see Brook, Troubled Empire (n. 90), 64-66.

111. Ann Bowman Jannetta, Epidemics and Mortality in Early Modern Japan (Princeton, N.J.: Princeton University Press, 1987), 14-15.

112. Leung, "Diseases of the Premodern Period in China" (n. 92), 354-55.

113. See Helen Dunstan's discussion of epidemics in a similar period of dynastic breakdown in China: "Late Ming Epidemics" (n. 78), 8-18. 
die-offs, took decades to spread from province to province, never blanketed the whole country, and killed less than 5 percent of the population. These epidemiological differences should be traced to differences in the environment and the available hosts and vectors. With plague, because it is not transmitted person to person (except in rare outbreaks of the primary pneumonic form such as in Manchuria in 1910-11), we always need to distinguish between the pathogen (Yersinia pestis) and the pathological signs and symptoms it produces in humans, on the one hand, and the epidemiology of the disease, dependent as it is on nonhuman hosts and vectors, on the other hand. ${ }^{114}$ The distinction is important for explaining not only why the Black Death in all likelihood did not reach India and may not have reached China in the fourteenth century, but also why plague behaved so differently in fourteenth-century Europe from the way it did in nineteenth- and twentieth-century India and China. ${ }^{115}$

GEORGE D. SUSSMAN is professor of history at LaGuardia Community College of the City University of New York. He is the author of Selling Mothers' Milk: The Wet-Nursing Business in France, 1715-1914 (University of Illinois Press, 1982) and of articles on disease and medical practice in nineteenth-century France. His current research concerns the global history of plague. His email address is gsussman@lagcc.cuny.edu.

114. For this argument I am especially indebted to Walløe, "Medieval and Modern Bubonic Plague" (n. 62), 60. See also Michel Drancourt, Linda Houhamdi, and Didier Raoult, "Yersinia pestis as a Telluric, Human Ectoparasite-Borne Organism," Lancet Infect. Dis. 6, no. 4 (April 2006): 234-41, which suggests how the Yersinia pestis bacillus might produce seven different epidemic "scenarios," depending upon a variety of hosts and vectors.

115. While this article was undergoing final revisions, an important paper on the genetic evolution of Yersinia pestis by a European team led by Giovanna Morelli appeared in Nature Genetics. Morelli's team compared the genetic sequences of seventeen $Y$. pestis samples from different sites around the world and constructed a phylogenetic tree of the bacterium. The authors argue that $Y$. pestis evolved through clonal mutation over 2,600 years ago from Yersinia pseudotuberculosis in China. The genotypes identified by Haensch and colleagues, "Distinct Clones" (n. 35), as responsible for the Black Death in Europe evolved more than 728 years ago (i.e., before 1282), according to Morelli's group. Although the authors clearly believe that the plague pathogen that ravaged western Eurasia in the fourteenth century reached the West from China via the Silk Road, they cannot confirm, based on the evidence of modern DNA, whether the evolution of the pathogen that caused the Black Death occurred in the West or China or whether the plague was also epidemic in China in the fourteenth century. Giovanna Morelli, Yajun Song, Camila J. Mazzoni, Mark Eppinger, et al., "Yersinia pestis Genome Sequencing Identifies Patterns of Global Phylogenetic Diversity," Nature Genet. 42, no. 12 (December 2010): 1140-43, doi:10.1038/ng.705. 